UDK: 811.111'37

DOI: 10.33669/KJ2021-32-04

primljeno / received: 5. 10.2021.

prihvaćeno / accepted: 3. 11.2021.
Izvorni naučni rad

\section{Džemajla Smlatić}

Pedagoški fakultet Univerziteta u Bihaću Ulica Luke Marjanovića bb, Bihać

Bosna i Hercegovina

dzemajlaa@gmail.com

\section{Belkisa Dolić}

Pedagoški fakultet Univerziteta u Bihaću Ulica Luke Marjanovića bb, Bihać

Bosna i Hercegovina

belkisa_dolic@hotmail.com

\title{
Konceptualne metafore sa sastavnicama žIVOT i SMRT u Kamenom spavaču Maka Dizdara
}

Sažetak: Konceptualna metafora je kognitivni mehanizam često i rado upotrebljavan u svim diskursnim tipovima s tim da u književnosti pokazuje svoje maksimalne domete budući da na učinkovit i originalan način demistificira iskustvo, percepciju i mentalne sheme određenog govornika - kao pripadnika kolektiva i kao individue. $\mathrm{U}$ ovome radu smo analizirali primjenu konceptualne metaforizacije u Kamenom spavaču autora Mehmedalije Maka Dizdara s konceptima žıvot i sMRT na poziciji ciljnih domena s namjerom propitivanja njezine svrhe, motiviranosti i kreativnosti. Upotrijebljene konceptualne metafore u zbirci jasan su odraz poimanja čovjekovog bitisanja u bogumilskoj duhovnoj tradiciji (izrazito negativna intoniranost ovosvjetske i poprilično pozitivna intoniranost onosvjetske zbilje), ali ispostavilo se i u univerzalnoj ljudskoj misli. Svakim novim uvidom u motivsko-tematski svijet Dizdareve poetike iznova se potvrđuje njezina formalna izuzetnost i sadržinska neiscrpnost, a ovaj put se to postiglo aparaturom kognitivne lingvistike, odnosno pronalaskom inovativnih metaforičkih izraza pri izražavanju konvencionalnoga konceptualnog metaforiziranja u Kamenom spavaču.

Ključne riječi: konceptualna metafora, izvorna domena, ciljna domena, bogumilstvo, univerzalnost, Kameni spavač 


\section{Uvod}

Metafora je dugo vremena posmatrana kao figura kojom stilizujemo i ukrašavamo govor te je kao takva pripisivana isključivo jeziku književnosti. Takvo, tradicionalno, stajalište o metafori može se svesti na pet obilježja: metafora je vlasništvo riječi - lingvistički fenomen, bazira se na sličnosti između dva poređena entiteta, predstavlja svjesno i samovoljno korištenje riječi od strane govornika koji je jezički kompetentan za tu radnju, koristi se u umjetničke i retoričke svrhe za postizanje posebnog efekta, tako da nije neophodna u svakodnevnoj komunikaciji, a kamoli za svakodnevnu misao i rezoniranje (up. Aristotel 2005).

Ovakva promišljanja o metafori su, napokon, dovedena u pitanje osamdesetih godina prošlog stoljeća kada se prvi put objelodanila teorija konceptualne metafore u knjizi Metaphors We Live By Georgea Lakoffa i Marka Johnsona. Lakoff i Johnson (1980) otkrit će da su koncepti kojima se svakodnevno vodimo, kojima percipiramo, razmišljamo i rasuđujemo - uvelike metaforični. Budući da su ti koncepti dio kognicije (koristimo ih automatski i nisu uvijek očigledni), njihova refleksija se očituje jedino u jeziku. Konceptualna domena iz koje izvlačimo metaforični izraz da bismo razumjeli drugu konceptualnu domenu naziva se izvorna domena (engl. source domain), dok je ona koju želimo razumjeti - ciljna domena (engl. target domain). Prva je obično konkretna, a druga apstraktna i njihov odnos nije reverzibilan (Kövecses 2002: 4). Sistematične korespondencije među domenama Lakoff i Johnson (1980) nazivaju metaforičkim preslikavanjem (engl. metaphorical mappings). Oni također nude model nazivanja konceptualnih metafora: CILJNA DOMENA JE IZVORNA DOMENA, te utvrđuju da se konceptualne metafore po nekim aspektima razlikuju, pa tako imamo: strukturalne metafore ("slučajevi u kojima je jedan koncept metaforički strukturiran u uvjetima drugog”), orijentacijske metafore (ne zasnivaju se na metaforizaciji jednog koncepta u smislu drugog, već organiziraju cijeli sistem koncepata da bi predstavile drugi sistem koncepata; većinom polaze od spacijalne orijentacije, npr. gore - dolje, u - izvan, naprijed - nazad, duboko - plitko i sl., te imaju svoju opoziciju) i ontološke metafore (kao ljudi, omeđeni tijelima i drugim granicama, skloni smo da namećemo 
umjetne granice na stanja, ideje i svakojake apstraktne koncepte ili da ih posmatramo kao materiju koju možemo mjeriti i kvantificirati). Iz rada ove dvojice autora iskrslo je novih pet obilježja metafore: metafora je vlasništvo koncepata, a ne riječi, funkcija metafore je bolje razumijevanje koncepata, a ne samo stilistička svrha, često nije bazirana na sličnosti, njena upotreba je svakodnevna bez obzira na "talenat" govornika i neizbježna je za svakodnevno mišljenje i rezoniranje. Zahvaljujući tim zaključcima, završila se era tradicionalnog posmatranja metafore, a započelo je istraživanje teorije konceptualne metafore unutar kognitivne lingvistike (Kövecses 2002).

Početkom 21. stoljeća teorija konceptualne metafore će samo učvrstiti svoje tlo. Naime, Lakoff (2008) je u saradnji s Jeromeom Feldmanom od 1988. godine radio na neuralnoj teoriji jezika (engl. Neural Theory of Language - NTL). Poznato je da se aktiviranjem određene neuronske grupe aktiviraju i druge. Hipoteza ovog istraživanja, između ostalih, bila je strukturiranje veza među domenama prilikom korištenja metaforičnih izraza. Drugim riječima, pokušalo se dokazati da li se misleći o ciljnoj domeni (konceptu ili neuronskoj grupi) aktivira izvorna domena te kako teče proces preslikavanja s domene na domenu. Podloga za ovo istraživanje je u samoj fizičnosti neuronskih procesa jer "mi mislimo mozgom. Nema drugog izbora. Misao je fizička. Ideje i koncepti koji ih proizvode su fizički 'izračunati' od strane moždanih struktura” (Lakoff 2008: 18). Ovime su zapravo samo potvrđene i dokazane teze iz Metaphors We Live By, kao što su: metafore su konceptualna preslikavanja ili mapiranja; dio su konceptualnog sistema, a ne samo jezički izrazi; postoji veliki sistem konvencionalnih metaforičkih mapiranja; taj sistem postoji fizički u mozgu, gdje se preslikavanja zaista dešavaju od domene do domene itd. (v. Lakoff 2008: 24).

Kritika na kognitivnu lingvistiku, tačnije na teoriju konceptualne metafore, tiče se činjenice da kognitivni lingvisti uveliko naglašavaju univerzalnost konceptualnih metafora i pritom zanemaruju činjenicu da strukturiranje konceptualnih metafora zavisi od našeg iskustva i percepcije te će direktno zavisiti od kulture i podneblja iz kojeg dolazimo (up. Kövecses 2005). Obje vrste činjenica potvrdile su se i u sklopu 
istraživanja konceptualne metafore u bosnistici, gdje su posebno zanimljivi radovi posvećeni stihovanom korpusu, odnosno radovi koji tematiziraju konceptualnu metaforu u poeziji te time identifikuju i demistificiraju svijetle primjere iskorištavanja metaforičkog koncepta u spoznajama ljudskog duha unutar bosanskohercegovačkoga književnog stvaralaštva (npr. Hodžić 2012; 2014, Smajlović-Šabić - Nikolić 2014; Spahić - Šabić 2020a; 2020b; Dolić 2020; 2021). U tekstu koji slijedi nastavljamo u tom duhu - analizirat ćemo konceptualnu metaforizaciju života i smrti u poetskom diskursu Maka Dizdara prije svega iz kognitivnolingvističke, ali i iz književnointerpretacijske perspektive. Ova tema se već razmatrala $\mathrm{u}$ kontekstu poimanja datih realija kroz raznolike interpretacije i književnu teoriju, a naša analiza će dodatno potvrditi slična, "nelingvistička", zapažanja.

\section{Riječ-dvije o korpusu}

Kao korpus za izradu ovog rada poslužila nam je zbirka Kameni spavač, kruna književnog stvaralaštva Maka Dizdara, u kojoj su se "sretno saželi i topli sjaj zavičajnog ognjišta i odsjaj univerzalnih saznanja ljudske sudbine” (Duraković 1991: 20), što je čini idealnom za prokazivanje jedinstvenosti i općenitosti konceptualnih metafora. Poznato je da su stećci i velika inspiracija i bitan motiv Kamenog spavača, što sugerira i samo ime zbirke. Ovdje ne mislimo samo na kulturnohistorijski spomenik već na sve ono što stećci predstavljaju za pjesnika. Dizdarevom pjesničkom viđenju bosanskohercegovačkoga srednjovjekovnog čovjeka podloga su upravo nekropole stećaka, po kojima je i nazvao neke pjesme (npr. Radimlja, Brotnjice, Mile, Krajina...). “On je u taj prvobitni doživljaj unio sve svoje životno, pjesničko i istraživačko iskustvo, ostvarivši jedinstven paralelizam između historijske slike, pjesničke vizije i filozofsko-estetskog pogleda na moderno doba i sudbinu čovjeka, na trajnost izvjesnih podataka ljudske sudbine" (Begić 1998: 356).

Stećke, koji nastaju u periodu od 12. do 15. stoljeća, prije svega vežemo za djelovanje Crkve bosanske, čije je učenje čest motiv ove zbirke. 
Bogumilstvo ${ }^{1}$ nastaje pod uticajem manihejstva, zoroastrizma, budizma i kršćanstva, a u osnovi učenja bio je dualizam, vjerovanje u borbu dobroga i zlog boga, svjetla i tame. Dakle, u njihovim učenjima postoje dva principa: dobro i zlo. Dobro je začetnik nevidljivog i duhovnog, a zlo vidljivog i tjelesnog. Crkva bosanska je bila uticajna u Bosni i prihvaćena od strane velikaša jer je naučavala na narodnom jeziku i time pomagala očuvati samostalnost Bosne od tuđih uticaja, a njeno učenje je bilo sličnije staroj slavenskoj vjeri nego kršćanstvu te je samim time i radije prihvaćano (up. Sarkić - Šertović 2013). Duraković (1991) u tom smislu kaže da se bogumilsko učenje u ovoj zbirci javlja kao alegorijska parabola o tragičnoj sudbini Bosne i njenih ljudi. Katnić-Bakaršić (2011) također govori o dvojakom značenju koje nose toposi kulture u Kamenom spavaču - jedno osnovno (predmetno) i drugo simboličko-metaforičko. "Kod Dizdara se i srednjovjekovna Bosna otkriva u svjetlu univerzalne ideje o sukobu dobra i zla, metafizike vlasti i ljudske istine" (Prohić 1998: 357).

Epitafi na stećcima su ono što je posebno inspirisalo Maka Dizdara: "Poznata je činjenica da je lapidarna pismenost bila potisnuta u stranu dug vremenski period, a zanimanje za nju pokazivali su uglavnom stručnjaci nekoliko profila, dok kod širih masa nije budila veliko zanimanje. Također je poznato i to, da je upravo ova pismenost uklesana na kamenu poslužila kao polazni motiv za stvaralaštvo Maka Dizdara, prije svega na njegov Kameni spavač i sakupljačke radove" (Sarkić Šertović 2013: 107). S tim u vezi, Dizdar preuzima i motive sa stećaka u svoju zbirku, često kao naziv pjesama (npr. Kolo, Ljeljeni, Sunce, Ruke, Mjesec...). ${ }^{2}$

Pored svih pobrojanih elemenata koji čine ovu zbirku jedinstvenom posebno mjesto zauzima jezik. “Toposi kulture u Dizdarevoj poeziji

Možda bi bilo uputnije upotrebljavati termin dualizam jer su oko termina bogumilstvo prisutne brojne rasprave i neslaganja. No, u ovom kontekstu nam se potonji čini nezaobilaznim budući da se i u Makovim bilješkama u Kamenom spavaču (npr. za pjesmu "Hiža u milama") navodi: krstjanin, krstijanin, pripadnik Crkve bosanske, bogumil.

2 U jezik Kamenog spavača Dizdar je pored motiva sa epitafa ugradio i motive iz bosanskih povelja, bosanskih evanđelja, manihejskih himni, natpisa, zapisa i usmenih predanja (v. Hodžić 2021). 
prepoznaju se i tematski i u odabiru leksike, okupljene u semantička polja što direktno stvaraju topose srednjovjekovne Bosne", od spomenutih toponima i motiva, do "naziva realija, zanimanja (hiža, dijak, kaznac, mitnica...), imena vladara i kamenih spavača (Gorčin, Kosara, ban Stipan Drugi, Jelena Gruba...), sakralnih elemenata što se povezuju sa heretičkom Crkvom bosanskom i/ili bogumilstvom (stub sunčani, sunčana počivališta, krstjanin, gost, starac...), ustaljenih elemenata dokumenata toga doba (i da e vidimo vsakomu komu se podoba - Zapis o časti; zapreštaju vam - Brotnjice)" (Katnić-Bakaršić 2011: 13). Korištenjem arhaizama uspostavljena je posebna veza s ostalim motivima iz srednjeg vijeka, a time je čitanje uveliko ubjedljivije. Kalajdžija (2013) tvrdi da je Kameni spavač u novijem dobu uspio skrenuti pažnju na stariji jezički izraz bosanskog jezika i time podići svijest o srednjovjekovnome starobosanskom jeziku. "Jedan od elemenata preko kojega Dizdar reafirmira ukupnost preispitivanja našeg odnosa prema prošlosti: kulturalnoj, tradicijskoj i identitarnoj, jeste i preko leksike. Zapravo, leksika je samo jedan od segmenata koji čine ukupnost slojevitosti jednoga književno-umjetničkog pogleda na svijet i povijest" (Kalajdžija 2013: 347-351). Što se arhaizama tiče, u Kamenom spavaču se može govoriti o dvjema osnovama iz kojih se crpe arhaični leksemi: staroslavenskoj, koja uključuje općeslavensku leksiku iz kanona i redakcija (a posebno bosanske), i starobosanskoj, koja uključuje nereligijsku leksiku "u kojoj je sublimiran jezični izraz nastao kao produkt narodnog srednjovjekovnog stvaralaštva”. Pored arhaizama, Dizdar poseže i za tvorbom novih riječi - neologizmima (ništiti, namrijeti, opepeliti, trikleto, žilište...), ali se tu ne zaustavlja pa, kombinirajući arhaizme i neologizme, nudi neologizirane arhaizme koje možemo nazvati "neoarhaizmima", a takvi su: tmica, žreci, zatok, Prazno-slovija, besćutje, istinia, tmuša, tmača, kupinje... (Ibidem).

Ako je Kameni spavač poruka o historiji Bosne, onda ona nije epsko-patriotska, već je "baladična ispovijest o praštanju i ljubavi, dobroti i čistoti življenja” (Duraković 1991: 22). Ako ova zbirka govori o životu, onda je život traganje za smislom. Ako ova zbirka govori o smrti, onda smrt nije kraj, već saznanje "neumitnog materijalnoga skončanja bića 
kao uvjeta preobrazbe u duhovnu supstancu u vječnost" (Durić 2013: 59). U svakom slučaju, mogućnosti čitanja Kamenog spavača - čini se - nemaju svoj konačan broj. U redovima koji slijede mi ćemo ponuditi samo jedan više: onaj iz kognitivnolingvističke perspektive, konkretnije iz perspektive teorije konceptualne metafore.

\section{Konceptualna metafora u zbirci "Kameni spavač“}

Turner (1987: 12) kaže da je dobra književnost moćna jer na majstorski način pobuđuje i manipulira našim kognitivnim aparatom. Pisci konstantno istražuju naše konceptualne i lingvističke strukture pa se zato neke ideje ljudskog uma mogu otkriti samo proučavanjem književnosti. $\mathrm{U}$ isto vrijeme, nemamo velike poteškoće pri razumijevanju književnih tekstova upravo zato što se autori također koriste onim figurativnim konceptima kojima i mi raspolažemo, sistematičnim korespondencijama između izvorne i ciljne domene te metaforičkim preslikavanjima. Konceptualne metafore o životu i smrti vrlo su česte u mnogim kulturama i postoje mnogobrojni primjeri za njih (npr. žIVOT JE DRAGOCJEN IMETAK u engleskom jeziku, v. Moritz 2015, SMRT JE UNIJA S BOGOM u španskom, v. Georgijev 2018). Razlog tome je vjerovatno što su u pitanju izrazito apstraktni pojmovi koje je čovjek pokušavao objasniti uz pomoć manje apstraktnih ili čak konkretnih pojmova od početka koherentne misli. Dizdarev način objašnjavanja je uronjen u bogumilsku viziju svega postojećeg.

\section{1. Život kao ciljna domena u Kamenom spavaču}

Premda se smatra da "je navodno postojala knjiga bosanskih krstjana nazvana Tajna knjiga iz 13. stoljeća u kojoj je bila zapisana njihova filozofija, kao i religijska načela, podatke o njihovu vjerskom sustavu donijeli su katolički izvori. Ovo poglavlje sinteza je raznih izvora koje donosi Katolička crkva o vjerskim naucima bosansko-humske hereze:

1. Vjera u 'dva Boga': prvo je vjera u 'većeg Boga', savršenstvo i dobrota, a drugo je 'manji Bog', koji je nesavršen i zao. Ovdje se možda i najbolje vidi utjecaj neomaniheizma i perzijskoga dualizma. 
2. Stvaranje duhovnoga i nevidljivog svijeta djelo je 'dobroga Boga'. Sve zle pojave i stvari potječu od Vraga, a on je Stvaratelj i svih materijalnih stvari.

3. Ljudske su duše anđeli i stvorene su od 'dobroga Boga'. Njih je Sotona prisilio da žive u ljudskome tijelu. Duše se mogu otkupiti isključivo krštenjem od strane Crkve bosanske (...)" (Kaučić 2020: 30).

Kao što vidimo, u duhu bogumilskog vjerovanja život je zatočeništvo $\mathrm{u}$ materijalnom svijetu i tijelu, poteklom od boga zla i nesavršenstva. Međutim, u pitanju je univerzalna konceptualna metaforizacija koju Lakoff i Turner (1989: 23) također tematiziraju i kažu da se za život može reći kako zarobljava dušu poput lanaca, okova ili neke druge sprave, a da je tijelo tamnica koja je zadržava. Iako je žIvot je zATočENIšTvo univerzalna konceptualna metaforizacija, načini njezinoga izražavanja su jedinstveni, o čemu najbolje svjedoče primjeri iz tematizirane zbirke:

"Satvoren u tijelu zatvoren u koži” (Prvo)

"Zarobljen u meso zdrobljen u te kosti” (Prvo)

“Zatvoren u rebra zarobljen od srebra” (Drugo)

“Otrgnut od neba žudiš hljeba vina” (Drugo)

"U žilište slišćen zatvoren u krvi” (Drugo)

"Zatvoren u mozak zarobljen u srce” (Četvrto)

“Oslobodi se svijeta prezri njegov cvijet” (Radimlja: vijenac)

“Ti tijelo njegovo tek uze / A tijelo to bijahu za njega - / Zatvor njegov" (Poruka)

"U kosti svoje ulovljeni u zemlji svojoj udomljeni” (Suočenje)... ${ }^{3}$

Od prethodne ontološke konceptualne metaforizacije zamjetno je produktivnija strukturna konceptualna metaforizacija žIVOT JE

3 Za ove primjere bi se moglo reći da za ciljnu domenu imaju fizičko, tj. ljudsko tijelo, pa bi se konceptualna metafora mogla izraziti i kao TIJELO JE ZATVOR. No, budući da tijelo percipiramo kao svojevrsnu konkretizaciju života, ipak smo izabrali ŽIVOT JE ZATOČENIŠTVO. 
PUTOVANJE. U pitanju je također univerzalna konceptualna metafora, koja počiva na nesumnjivim sličnostima između iskustveno bližeg koncepta putovanja (putnik, odluka i pripreme za put, polazak, prijeđena udaljenost, prepreke na putu, uživanje na putu, saputnici, duljina puta, odredište, iduće putovanje) i iskustveno daljeg koncepta života (čovjek, začeće i prenatalni razvoj, rođenje, protok života, životna iskušenja, životne radosti, porodica / prijatelji / emotivni partner(i), životni vijek, smrt, život poslije smrti) na koje se vrši preslikavanje i biva popraćeno odgovarajućim jezičkim izrazima, bilo konvencionalnim, bilo inovativnim (Dolić 2021: 23 i 24). Osim toga, kada govorimo o životu, naglašavaju Lakoff i Turner (1989), često govorimo o ispravnim i neispravnim putevima, to jest putevima dobra i zla, a smrt nas svakako vreba kroz cijelo naše putovanje. Upravo to je i smisao svih primjera ove metafore $\mathrm{u}$ analiziranoj zbirci:

“Ti poznaješ uklesane i utrte pute / I niti jedan drugi / (A mali su zapravo i jalovi / Bez obzira koliko su / Za tebe / Oholog i jakog / I preteški / I / Dugi)” (Putevi)

“Ti ne znaš zakon raskrsnice / između svjetlila / I / Tmice” (Putevi) “Ti ne znaš ništa o mojoj mapi putova” (Putevi)

"Hodeći kroz zemlju / Kroz noći kroz dane” (Pravednik)

"na putu kroz žitije sije on bugario nije / put žarka sunca gledao je i modra neba” (Zapis na dvije vode 1.)

"Kroz dane kroz godine kroz stoljeća hodimo za suncem / visokim kroz kamenje i šume ledenog gorja onog” (Suočenje)

“Tek što si pošao izgubio si se već na tom kratkom putu / traganja" (Poruka u mramorje prispjelom)

"Povratka više nema / I dalje ćeš tako beznadno ići / I stići od bola do bola što se za te sprema" (Poruka u mramorje prispjelom)

"Dobar dan dobri dane dobrom danu još uvijek dobrimo / Kroz kupinje crno kroz drače vremena kroz vražije kroz vrače" (Brotnjice) 


\section{"Krčimo kroz grče kroz sulude grane kroz dane od lane / Kroz dane od sjutra Kroz ova nam jutra Sve kroz žive / rane” (Brotnjice) \\ "Na putu ovom / Sada smo prvi put zastali" (Brotnjice) \\ "Bez družbe što ostah hudo je na putu pustom" (Nevoljni vojno)}

Čovjek, ostala bića te sve drugo u pojavnom svijetu prolazi kroz određene faze svog bivstvovanja, "koje se ponavljaju po uočljivom ili utvrđenom redu od početnog preko niza međustanja natrag do početnog” čineći jedan ciklus, dakle kružni proces koji nikad ne prestaje (HJP). Dvije konceptualne metafore u zbirci počivaju na tom načelu: 1 . ŽIVOT JE KOLO (prepoznajemo kolo kao motiv sa stećka, uzet za poseban stilistički element upravo zato što kolo čini jedan zatvoren oblik, tačnije krug):

"U tom kolu bola / Potonji il' / Prvi” (Četvrto)

"U tom kolu bola ni potonj ni prvi / Igrište si strvi i ročište crvi" (Peto)

"Ruka do ruke / luka do luke / Ruka u ruci / muka u muci” (Kolo)

"Koliko kola od dola do dola / Koliko bola od kola do kola / Kolo do kola od bola do bola" (Kolo bola)...

i 2. ŽIVOT JE SMJENA GODIŠNJIH DOBA. Motiviranost ove konceptualne metafore podložna je lahkom razumijevanju prilikom čitanja bilo kojega književnog teksta. Sasvim je prirodna ovakva koncepcija života, navode Lakoff i Turner (1989), budući da su proljeće i ljeto vrijeme buđenja i pupanja biljnog i životinjskog svijeta, dok su jesen i zima vrijeme plodonošenja te odumiranja i hibernacije. Prilikom korištenja ove metafore proljeće je obično rođenje, ljeto mladost, jesen starost ili blizina smrti, dok je zima sama smrt, odnosno kraj. Nije drugačije ni kod Dizdara:

"Ja sam samo onaj što iz svoje jeseni / Iz zatoka tvari iz te tvarne muke / U ona daleka sunčana počivališta / Pruža / Ruke” (Radimlja: sunčani Hristos) 
"Snjegovi postaju sve dublji i crnji kao grijesi / U životu koji se bliži svom kraju / Hoćemo li još uvijek imati oči / Kada jabuka u vrtu pusti prvi bijeli cvijet?" (Jabukov cvijet)...

$\mathrm{U}$ tom zatočeništvu, na tom putovanju, u tome neprekidnom ciklusu, čovjek je u konstantnom ratu sa sobom i svime oko sebe. Život je prožet nevoljama i opasnostima, pa nimalo ne čudi kad se leksemi iz semantičkog polja borbe koriste prilikom opisivanja života, tačnije nedaća koje su njegov sastavni dio. Sljedeći primjeri ponajbolje opisuju konceptualnu metaforu žIVOT JE воRBA ${ }^{4} \mathrm{u}$ istraživanoj zbirci:

"Jer najmanje znaš da u svome žiću / Najteža rvanja su / I ratovi pravi / U samome / Biću” (Putovi)

"Od te ruke dvije tvoja jedna nije / Jedna drugu ko da / Hoće da pobije?" (Treće)

"Sa ove mračne strane vrata nadire vjetar hudi razdire / vjetar ludi / Ostavljam sestru i brata ostavljam oca i majku između / zvijeri i ljudi" (Radimlja: vrata)

"Pa teško onim koji žive na kopnu teško onima na moru / Jer opaka zvijer raširi krila i sakri zoru / Znajući da vremena ima malo / I kuga bi i rat i glad pa žvatasmo jezike svoje od bola / I davasmo ruke svoje i davasmo vrelu krv i srca gola" (Radimlja: vijenac)

"Kako si nježan i krhak / A treba da živiš / Treba da živiš med ljudima a riječi nemaš / Treba da živiš med vucima a zuba nemaš / A kako ćeš tek razlikovati čovjeka i vuka” (Uspavanka)

"Ruke su tvoje plavi dozivi zore / A njima valja da se hvataš u koštac / Da dijeliš bojeve na razmirjima / Sa zmijskim čudima u kojima živi aždahaka” (Uspavanka)

"Hraniću te vodicom iz kljuna laste / Da ozubatiš za kletvu na zlotvora / Da progučeš za dobrodušna namjernika” (Uspavanka)

4 I ova konceptualna metafora je univerzalna. Naprimjer, Kövecses (2005) govori o konceptualnoj metafori žIVOT JE RAT u mađarskom jeziku. 


\subsection{SmRt kao ciljna domena u Kamenom spavaču}

Među svim upotrijebljenim konceptualnim metaforama u zbirci Kameni spavač najbrojnije su one s ciljnom domenom smrt. To nas, naravno, nimalo ne začuđuje ako uzmemo u obzir metaforičke i simboličke značajke ove zbirke - osnovni motiv su natpisi sa stećaka, nadgrobnih spomenika. U Kamenom spavaču smo pronašli višestruke načine konceptualizacije smrti. Lakoff i Turner (1989) ističu da metafore obitavaju najprije u misli, a potom u jeziku - postoji generalna konceptualizacija smrti u čovjekovoj misli kao odlaska, a ona se u jeziku može izreći na različite načine. U tom smislu, eufemizmi koje koristimo za smrt (npr. preselio/la je, napustio/la nas je...) nisu arbitrarni ${ }^{5}$ te su posve sigurno pokazatelji našega generalnog poimanja smrti kao odlaska. Pojmovi poput života i smrti toliko su sveobuhvatni da nije moguće koristiti jednu konceptualnu metaforu koja bi nam omogućila njihovo shvaćanje.

Prva kojoj ćemo ovdje ustupiti mjesto jeste SMRT JE IZBAVLJEnJE. Kao što smo ranije imali priliku vidjeti, bogumili su vjerovali da je bog dobra i savršenstva začetnik svega duhovnog i nevidljivog, što uključuje i ljudsku dušu, koja je odlukom sotone prisiljena živjeti u tijelu. Činom smrti ona biva izbavljena iz toga strašnog zatočeništva. Lakoff i Turner (1989) također spominju opozitne konceptualne metafore žIVOT JE ZATOČENIŠTVO i SMRT JE IZBAVLJENJE u kojima je život shvaćen kao tjelesna tamnica, a smrt kao izbavljenje iz nje. Primjeri na koje smo mi naišli u zbirci u vezi s ovom metaforom uključuju sljedeće metaforičke jezičke izraze (mahom glagolske pridjeve trpne):

“Zarobljen u meso zdrobljen u te kosti / Prostor taj do neba kako da premosti” (Prvo)

"Satvoren u tijelu zatvoren u koži / Sanjaš da se nebo sa tom zemljom složi” (Drugo)

“Zatvoren u mozak zarobljen u srce / U toj tamnoj jami vječno zoveš sunce / Sanjaš da se nebo umnoži i vrati” (Četvrto)

5 Naravno, nisu ako posmatramo konceptualizaciju jedne zajednice koja ima konsenzus oko toga kako se nešto kaže. 
"Ostavi zato oca i majku ostavi brata i sestru / Oslobodi se svijeta prezri njegov cvijet” (Radimlja: vijenac)

"U kosti svoje ulovljeni u zemlji ovoj udomljeni / Da upustimo se strasno u zagrljaj sa svojim slatkim jadom” (Suočenje)

“Ti tijelo njegovo tek uze / A tijelo to bijahu za njega - / Zatvor njegov / I njegove / Suze" (Poruka)

Jedna od učestalijih konceptualnih metafora u svakodnevnom govoru SMRT JE PUTOVANJE KA KONAČNOM ODREDIŠTU ${ }^{6}$ prisutna je - očekivano - i u zbirci Kameni spavač. Ona oslikava ne samo bogumilska nego i ostala religijska uvjerenja da je život trenutačni, a smrt trajni dom:

"Pa izreko slovo / Dižuć glavu k nebu / Pitajuć o tajni / Na putu ka grebu" (Pravednik)

“Tako tijelo stade / Na putu kroz tminu / Pade...” (Pravednik)

"i kad obvlada ga brijeme stade u vrijeme / na tom putu pade dosegavši tamu samo svoga greba" (Zapis na dvije vode)

"Jer snebi se prestrašen od jednog smrtnog brijega / Ti opet nevoljan stiže na drugi brijeg neumitne smrti" (Poruka u mramorje prispjelom)

"Sva nasušna slova spletena od greba / Što me zaustavi u kretanju bonom / Bol da pojača na putu / Ka onom” (S podignutom rukom) "Kroz cvijetja proljetja kroz kose smrti tražim ušće u te zlatne dveri” (Radimlja: vrata)

"S morom na grudima sa zorom u zjenama srljamo slanom gorkomodrom morju" (Suočenje)

$\mathrm{Na}$ nju možemo nadovezati sljedeću konceptualnu metaforu, koja se može formulisati kao SMRT JE VJEČNo POČIVAlišTe. Ova metafora, kako kažu Lakoff i Turner (1989), koristi se primarnijom metaforom

6 I ne samo na našem govornom području - npr. DEATH IS DEPARTURE (Lakoff Turner 1989). 
STANJA SU LOKACIJE, gdje smrt postaje vječno (u našim primjerima sunčano) počivalište:
"ne treba mu ništa / do sunčanih počivališta" (Zapis na dvije vode)
"Ja sam samo onaj što iz svoje jeseni / Iz zatoka tvari iz te tvar- ne muke / U ona daleka sunčana počivališta / Pruža / Ruke” (Radimlja: sunčani Hristos)

Konceptualnoj metafori SMRT JE VJEČNO POČIVALIŠTE jako je bliska metafora SMRT JE SAN. U mnogim kulturama (uključujući i bogumilsku) smrt se doživljava kao vječni san ili odmor. "Kako je smrt specifična vrsta odlaska - jednosmjeran put, put bez povratka, tako je smrt specifična vrsta sna - vječni san iz koga se nećemo probuditi” (Lakoff Turner 1989: 19). Metaforični izrazi upotrijebljeni u Kamenom spavaču slikovito to dočaravaju:

"Davno sam ti legao / I dugo ti mi je ležati” (Zapis o vremenu)

“Ti ćeš živjeti i kad ti se oči sklope” (Uspavanka)

Ako smrt poimamo kao putovanje u neki drugi svijet ili dom, onda se ona može smatrati svojevrsnim prelaskom ili preseljenjem. SMRT JE PRESELJENJE zapravo je vrlo česta konceptualna metafora u svakodnevnom govoru našeg podneblja, kao posljedica religijsko-kulturnog kruga, što se napose očitalo i u Kamenom spavaču. Iako značenjski ekvivalentna s metaforom SMRT JE PUTOVANJE KA KONAČNOM ODREDIŠTU, njih dvije ipak nisu jezički ekvivalentne (zbog korištenja specifičnih metaforičnih izraza koji ih diferenciraju), stoga primjere navodimo zasebno:

“Zemlja je smrtnim sjemenom posijana / Ali smrt nije kraj. Jer smrti zapravo i nema / I nema kraja Smrću je samo obasjana / Staza uspona od gnijezda do zvijezda" (Smrt)

"I trebalo bi već jednom preći u krug svjetlosti / Kroz neka uska vrata trebalo bi se vratiti / Iz tijela ovog golog u tijelo vječnosti” (Radimlja: vrata)

"Kroz cvijetja proljetja kroz kose smrti tražim ušće u te / zlatne dveri” (Radimlja: vrata) 
“ima jedna modra rijeka - valja nama preko rijeke” (Modra rijeka)

"Sve dalje je vode preko mutne vode" (Kosara)

Dosad pobrojane metafore u ovom poglavlju mogu se smatrati potkonceptima posljednje metafore ovog tipa - SMRT JE ODLAZAK - budući da svaka od njih upućuje na neku vrstu odvajanja od života kao prostora. U zbirci se pak mogu naći i primjeri u kojima se jezički ne identifikuje posmrtno odredište niti se otkrivaju detalji oko odlaska. Takve stihove najčešće nalazimo kod pjesama koje za podlogu imaju epitafe. Naime, osoba koja nam se s epitafa obraća u stanju je neznanja o pitanju svega posmrtnog, ona se oprašta od onih koji ostaju ili ih upozorava:

"Oprostite mi / što ipak vas molju / i bratiju i družinu i gospodu / do vratiju mojih da dođu da me pohodu" (Zapis na dvije vode)

"Ostavi zato oca i majku ostavi brata i sestru / Oslobodi se svijeta prezri njegov cvijet” (Radimlja: vijenac)

"Sada u končini / Odlazim” (Zapis o odlasku)

"Vas koji ste čisti sad mačem će da gone sa svakoga stanka / I kao podvig hvaliće čas tvog mučnog i mučkog rastanka” (Radimlja: vijenac)

"Ostavljam sestru i brata ostavljam oca i majku između zvijeri i ljudi / Da sebe budem našao u svom biću na putu svom stubu sjaja" (Radimlja: vrata)

Putem ontoloških metafora konceptima, stanjima i emocijama dajemo oblik ili određujemo količinu. Ako nekom stanju dajemo antropomorfne osobine, onda je svakako riječ o personifikaciji. Personifikacija pokriva širok spektar metafora od kojih svaka bira specifične aspekte osobe ili načine na koji se ona percipira, a svima njima je zajedničko to da su dio ontoloških metafora i da nam omogućuju pridruživanje smisla različitim fenomenima u svijetu prema ljudskim mjerilima - mjerilima koje možemo razumjeti na temelju naših osobina, ponašanja, motivacija i karakteristika (Lakoff - Johnson 1980: 34). Kao dio konceptualne metafore personifikacija je vrlo česta u svakodnevnoj jezičkoj upotrebi, a svoje mjesto je našla i u Kamenom spavaču. Prvi tip personifikacije 
smrti prepoznaje njen smisao u pratnji čovjeka u zagrobni svijet ili u vječni život te je stoga nazivamo SMRT JE VODIČ U VJEČNI ŽIVOT:

“Žih / a smrt dozivah / Noć i dan” (Gorčin)

"On čeka me od vijeka / On čeka i vidim ga zacijelo / I silazim $\mathrm{k}$ njemu / Kroz to bijelo / lozje” (Radimlja: loza i njene rozge)

"On mi reče a da ga ne upitah / Ja sam ta porta i kroz nju uđi u mene jako ja u tebe" (Radimlja: vrata)

"I davasmo ruke svoje i davasmo vrelu krv i srca gola / Želeći smrt al smrt je od nas bježala” (Radimlja: vijenac)

“Zemlja je smrtnim sjemenom posijana / Ali smrt nije kraj. Jer smrti zapravo i nema / I nema kraja Smrću je samo obasjana / Staza uspona od gnijezda do zvijezda" (Smrt)

Druga personifikacija smrt predstavlja kao dušmanina - SMRT JE NEPRIJATELJ, koji neumorno radi u korist našeg kraja ili ga strpljivo čeka:

"Raširivši ruke od prsta do prsta / On pobijedi / Smrt" (Radimlja: sunčani Hristos)

"Smrt ga tražaše al ne nađe ništa / Ne nađe ni kosti ni meso ni krvi / Osta joj samo obris znameni i prvi / Put za nešto smrt zube nije imala / Gle kako sad bezglavo skače / Plače i rida očajna / I mala" (Radimlja: sunčani Hristos)

"Ja sam samo onaj koji je u sjeni / Onog što mu smrt ne mogaše ništa" (Radimlja / sunčani Hristos)

"Stog uzmi štit i oklop izvuci mač na svoje goniče / Kroz smrt uništi smrt” (Radimlja: vijenac)

“Ti si nakanio da mene nema” (Putovi)

“Ti si nakanio da me pod svaku cijenu uništiš" (Putovi)

"I zato i tako smrti nikad ne poiska / Al smrt je uza nj vavijek bila / Prisutna I / Bliska" (Zapis o vitezu) 
"I u toj noći boja velega / Tuj smrtni junak smrti ne dopade" (Zapis o vitezu $)^{7}$

U uvodnom poglavlju ovoga rada spomenuli smo i orijentacijske metafore, gdje pomoću pri(jed)ložnih izraza smještamo apstraktne koncepte u prostor. Za jednu takvu metaforu - SMRT JE DOLJE - našli smo nekoliko primjera u zbirci Kameni spavač:

"A na dnu smrti / boje će ubo biti bolje" (Prepoznavanje)

"On čeka me od vijeka / On čeka i vidim ga zacijelo / I silazim k njemu / Kroz to bijelo / lozje” (Radimlja: loza i njene rozge)

"na tom putu pade dosegavši tamu samo svoga greba" (Zapis na dvije vode)

Posljednji stih može se uzeti i kao primjer za posljednju konceptualnu metaforu koju smo izdvojili: SMRT JE TAMA. Ova metafora dio je generalnije metafore žIVOT JE DAN, gdje je jutro rođenje, podne mladost,

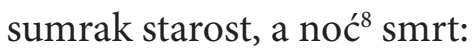

"Smrću mojom umro je i moj svijet / U prazne oči / Mrak se / Pradavni / Naseli" (Svatovska)

\subsection{Značenjski odnosi među konceptualnim metaforama o životu i smrti}

Nakon što smo formulisali, oprimjerili i objasnili motiviranost konceptualnih metafora koje za ciljne domene imaju život i smrt u Kamenom spavaču, nameće se potreba da ih na neki način ujedinimo, odnosno grupišemo, s obzirom na značenjske odnose koji među njima postoje. Naime, leksemi "život" i "smrt" na paradigmatskoj i sintagmatskoj osi bosanskoga jezika uglavnom ${ }^{9}$ stoje u odnosu antonimije (nasuprot života je smrt i obratno), ${ }^{10}$ neposredno i posredno. Pod ovim

7 Posljednje dvije konceptualne metafore se mogu podvesti pod konceptualno metaforiziranje SMRT JE OSOBA, odnosno DEATH IS A PERSON u Lakoff i Turner (1989).

8 Up. sa DEATH IS NIGHT i DEATH IS SILENCE kod Lakoff i Turner (1989).

9 Rijetko hip(er)onimije, odnosno meronimije (smrt je sastavni dio života, ali ne i obratno).

10 Suprotnost među njima postoji i u (gramatičkom) rodu. 
potonjim mislimo na primjere kada život i smrt imenujemo drugačije, ali ne sinonimima, nego metaforičkim jezičkim izrazima. Iz ustroja konceptualnih metafora izdvojenih iz tematizirane zbirke proizilazi da je prema Dizdarevom viđenju Crkve bosanske život za njene pripadnike predstavljao: zatočeništvo, putovanje, svjetlost, dan, ljeto, borbu, dolazak i negdje gore, dok je smrt predstavljala: izbavljenje, konačno odredište, tamu, noć, zimu, počivalište, odlazak i negdje dolje. Iako smo od bogumila udaljeni nekoliko stoljeća, naše i njihovo poimanje života i smrti nije se puno udaljilo, ako uopće i jeste.

Dominantna religija u Bosni i Hercegovini danas je islam, s kojom učenje Crkve bosanske ima nekih dodirnih tačaka, između ostalog i viđenje života na trenutnom (dunjaluk) te na budućem svijetu (ahiret), o čemu najbolje svjedoče riječi Božijeg vjerovjesnika Muhameda, a. s.: "Dunjaluk je tamnica za vjernika." Ništa drugačije nije ni u ostalim monoteistističkim religijama. Unatoč tome, kod svih ljudi - dakle i ovdje i drugdje - postoji želja za što dužim ostankom na ovom svijetu, kakav god da je (lagodan ili paćenički). I neopisiv strah od odlaska s njega jer, ma koliko pravovjerni vjerovali u postojanje drugog / savršenog / vječnog svijeta, smrt za svakog predstavlja nešto nepoznato, neiskustveno. Upravo se u tome ogleda prividna kontradiktornost u promišljanjima o smrti općenito, ali i u ovoj zbirci (ona je u jednom slučaju izbavitelj, a u drugom neprijatelj). ${ }^{11}$

O zavičajnom i istovremeno univerzalnom u Kamenom spavaču poentirao je Šator (2004: 111):

Govoreći o općim životnim temama, koje su oduvijek preokupirale religiju i filozofiju, ali i poeziju, Mak Dizdar je nastajao da u vraćanju vjerovanju pripadnika Crkve bosanske, Dobrih Bošnjana, iskaže tu vjekovnu muku srednjovjekovnog bosanskog čovjeka jezikom koji je spoj savremenog idioma i dalekog jezičnog idioma svojih predaka, pokazujući istovremeno muku i dramu savremenog čovjeka. Spajajući zavičajno i univerzalno, Mak Dizdar na taj je način pokazao da te općečovječanske teme mogu biti iskazane i jezikom Bosne i njenih dalekih predaka. Ustvari, taj starobosanski jezik ovaj pjesnik nije smatrao mrtvim, nego

11 Za pogled na sistem društvenih vrijednosti i konceptualizaciju društvenih realnosti putem metaforizacije v. Maslo (2012) i Mujagić (2019). 
nepravedno zaboravljenim i odbačenim, pa je u pjesničkoj verbalnoj preobrazbi stara bosanska riječ postajala savremena i sasvim modema. U njegovoj poeziji transmutacija starog bosanskog jezika iz povelja, starih spisa, sa stećaka, u moderni pjesnički iskaz urađena je bez nacionalne mitologije, bez patetike i glorifikovanja te prošlosti. Uspješan spoj tog arhaičnog bosanskog jezika i modernog poetskog iskaza rezultirao je izuzetnim pjesničkim tvorevinama čiji jezik ne samo da stvara atmosferu tih minulih vremena nego iskazuje "najhumanija shvatanja i osjećanja univerzuma - čovjeka u svijetu".

\section{Zaključak}

Kao relativno novo polje u lingvistici, konceptualna metafora kod nas u bosnistici nije dovoljno istražena, ali u posljednje vrijeme postoji veliki interes za njeno izučavanje, naročito u stihovanom korpusu. U ovom radu istraživali smo konceptualnu metaforu u pjesništvu Mehmedalije Maka Dizdara, jednog od najistaknutijih bosanskohercegovačkih književnika. Njegov književni rad objedinjuje uticaje iz bosanske srednjovjekovne kulture (prvenstveno Crkve bosanske i za nju vezanih stećaka) i islamskog misticizma. Njegovo najznačajnije književno djelo je zbirka poezije Kameni spavač, koja se ogleda se u visokoj duhovnosti, a tematski u univerzalnoj tematici propitivanja života i smrti, pitanja porijekla, dolaska, odlaska, ali ponajviše konkretnih, egzistencijalnih pitanja ljudskog roda i društvenih odnosa u (kulturnoj) historiji.

Kameni spavač očekivano obiluje primjerima konceptualizacije života i smrti pomoću konkretnih ili bar manje apstraktnih fenomena - kako god, iskustveno bližih. U većini slučajeva ustroj konceptualnih metafora nosi opozitan predznak jer na pozicijama kako ciljnih tako i izvornih domena stoje svojevrsni antonimi (npr. žIVOT JE ZATOČENIŠTvo vs. SMRT JE IZBAVLJENJE). Kod svih izdvojenih primjera konceptualne metaforizacije motiviranost proistječe iz bosanskohercegovačke kulturne prošlosti, ali je njihova primjenjivost moguća i na savremeni religijsko-kulturni krug kojem pripada Bosna i Hercegovina. I ne samo na njega! Korištenjem literature američkih lingvista pri obradi bosanskoga korpusa, došli smo do zaključka da konceptualne metafore koje za komponente imaju koncepte život i smrt nisu ograničene za neko 
vrijeme ili podneblje, već su itekako univerzalne, što nimalo ne iznenađuje jer su i spomenuti koncepti upravo takvi.

\section{Izvor}

Dizdar, Mak (1991): Kameni spavač: Izabrane pjesme, Svjetlost, Sarajevo.

\section{Literatura}

Aristotel (2005): O pjesničkom umijeću, Školska knjiga, Zagreb.

Begić, Midhat (1998): “Epitafi kao osnova poeziji”, U: Bošnjačka književnost u književnoj kritici. Knjiga 3. Novija književnost - poezija, Alef, Sarajevo, 350-356.

Dolić, Belkisa (2021): Ogledi o rodu i jeziku. Diskursna, pragmatička i gramatička analiza, Pedagoški fakultet u Bihaću, Bihać.

Dolić, Belkisa (2020): "Konceptualne metafore žENA JE BILJKA i MUŠKARAC Je Žıvotinja u poemi 'Na pravi put sam ti, majko, izišo' Skendera Kulenovića”, Hercegovina 19, 239-257.

Duraković, Enes (1991): “Govor i šutnja tajanstva”, u: Duraković, Enes (ur.), Mak Dizdar. Kameni spavač: izabrane pjesme, Svjetlost, Sarajevo, 5-44.

Durić, Rašid (2013): "Artizam smrti kroz simbiozu estetike i svetosti u Kamenom spavaču Maka Dizdara", u: Hadžizukić, Dijana; Šator, Edim (ur.), Zbornik radova: Slovo o Maku, Fakultet humanističkih nauka Univerziteta "Džemal Bijedić", Mostar, 57-78.

Georgijev, Ivana (2018): "Metafore o smrti i umiranju u španskom i srpskom jeziku”, Godišnjak Filozofskogfakulteta u Novom Sadu XLIII/2, 181-194.

HJP - Hrvatski jezični portal, hjp.znanje.hr (pristup 5. 10. 2021).

Hodžić, Jasmin (2012): "Metaforički koncept žIVOT JE IGRA na primjeru kur’anskog teksta: Kognitivno-semantička analiza”, Istraživanja, Časopis Fakulteta humanističkih nauka 7, 99-108.

Hodžić, Elmedina (2021): Doprinos Mehmedalije Maka Dizdara lingvističkoj bosnistici, magistarski rad, Univerzitet "Džemal Bijedić" u Mostaru, Fakultet humanističkih nauka, Mostar. 
Hodžić, Jasmin (2014): "Metaforički koncept LJUdSKA BIĆA su ŽIvotinje u poeziji Muhameda Elezovića", u: Akbarov, Azamat (ur.) Linguistics, Culture and Identity In Foreign Language Education, International Burch University, Sarajevo, 1027-1031.

Kalajdžija, Alen (2013): "Arhaizmi i neologizmi u Kamenom spavaču - leksikografski pristup", u: Hadžizukić, Dijana; Šator, Edim (ur.), Zbornik radova: Slovo o Maku, Fakultet humanističkih nauka Univerziteta "Džemal Bijedić", Mostar, 347-358.

Katnić-Bakaršić, Marina (2011): “Kultura i pamćenje u 'Kamenom spavaču' Maka Dizdara", Pregled. Časopis za društvena pitanja 1 (1), 9-24.

Kaučić, Domagoj (2020): "Bosanski krstjani - religijska načela i utjecaj u srednjovjekovnoj Bosni", Essehist 10, 25-31.

Kövecses, Zoltán (2002): Metaphor: a practical introduction, Oxford University Press, New York.

Kövecses, Zoltán (2005): Metaphor in Culture: Universality and Variation, Cambridge University Press, Cambridge.

Lakoff, George (2008): “The neural theory of metaphor”, u: Gibbs, R. (ur.) The Cambridge Handbook of Metaphor and Thought, Cambridge, Cambridge University Press, 17-38.

Lakoff, George; Johnson, Mark (1980): Metaphors We Live By, The University of Chicago Press, Chicago.

Lakoff, George; Turner, Mark (1989): More than Cool Reason: A Field Guide to Poetic Metaphor, The University of Chicago Press, Chicago.

Maslo, Adi (2012): "Shaping Value Systems by Means of Conceptual Metaphor - American Inaugurals", https://www.academia.edu/4570495/Shaping_ Value_Systems_by_Means_of_Conceptual_Metaphor_American_ Inaugurals (pristup 18. 10.2021).

Moritz, Ivana (2015): Kognitivna analiza eufemizama u političkom diskursu na engleskom jeziku, doktorski rad, Filozofski fakultet, Osijek.

Mujagić, Mersina (2019): Metaforizacija izbjegličke krize u britanskom i bosanskohercegovačkome medijskom diskursu, doktorska disertacija, Filozofski fakultet Univerziteta u Sarajevu, Sarajevo. 
Prohić, Kasim (1998): “Razmirje: Koraci na rubu oštre jave”, u: Bošnjačka književnost u književnoj kritici, Knjiga 3, Novija književnost - poezija, Alef, Sarajevo, 357-378.

Sarkić, Sanela; Šertović, Mirela (2013): “Odnos između kulturnog spomenika i revitalizacije srednjevjekovne kulture u pjesništvu Maka Dizdara”, u: Hadžizukić, Dijana; Šator, Edim (ur.). Zbornik radova: Slovo o Maku, Fakultet humanističkih nauka Univerziteta "Džemal Bijedić", Mostar, 107-122.

Smajlović-Šabić, Indira; Nikolić, Marijana (2014): "Konceptualna metaforizacija stihova sa somatskom sastavnicom srce unutar sevdalinki”, Journal of Foreign Language Teaching and Applied Linguistics, 107-120.

Spahić, Vedad; Šabić, Indira (2020a): "Mlada je kula izdaleka: Konceptualne metafore i njihove ekstenzije u pjesmi 'Gradačac' Milorada Pejića”, Post Scriptum VIII/IX, 119-130.

Spahić, Vedad; Šabić, Indira (2020b): “Trube na prelazu kod Parkuše: Kognitivno metaforiziranje sinovljevske ljubavi u pjesmi 'Moja majka' Gorana Samardžića”, Croatica et Slavica Iadertina 16/2, 405-413.

Šator, Muhamed (2004): “Transmutacija srednjovjekovnog jezika u Kamenom spavaču”, Književni jezik 22/1-2, 110-121.

Turner, Mark (1987): Death Is the Mother of Beauty: Mind, Metaphor, criticism, The University of Chicago Press, Chicago. 


\title{
Conceptual metaphors with the components LIFE and DEATH in the Stone Sleeper by Mak Dizdar
}

\begin{abstract}
Conceptual metaphor is a cognitive mechanism often and gladly used in all discourse types, but it shows its maximum potentials in literature as it demystifies in an efficient and unique manner the experience, perception and mental schemas of a particular speaker - as both a member of a group and an individual. This paper analyzes the application of conceptual metaphorization in Mehmedalija Mak Dizdar's Stone Sleeper with the concepts of LIFE and DEATH in the position of target domains with the aim of questioning its purpose, motivation and originality. The conceptual metaphors used in the collection are a clear reflection of the notion of human existence in the Bogumil spiritual tradition (the extremely negative intonation of the worldly and the rather positive intonation of the otherworldly reality) but, as it also turned out, in universal human thought. With each new insight into the motivic-thematic world of Dizdar's poetics, its formal exceptionality and inexhaustibility of content are reaffirmed. This time, it was achieved using the apparatus of cognitive linguistics, $i$. e. by finding innovative metaphorical linguistic units expressing conventional conceptual metaphorization in Stone Sleeper.
\end{abstract}

Keywords: conceptual metaphor, source domain, target domain, Bogomilism, universality, Stone Sleeper

Izjava autora o nepostojanju sukoba interesa i poštivanju općih etičkih kodeksa:

Autor potvrđuje da ne postoji nikakav stvarni ili mogući sukob interesa vezan za ovaj tekst te da je tekst napisan u skladu s etičkim kodeksima prema preporukama COPE (Committee of Publishing Ethics). 